\title{
The Law Enforcement of The Employees Social Security System in Indonesia: A Game Theory Perspective
}

\author{
"Randy Amsyari, "*Fajrin Satria Dwi Kesumah \\ * Adelaide Business School, Faculty of Professions, The University of Adelaide, \\ Australia \\ ** Department of Management, Faculty of Economics and Business, Universitas \\ Lampung, Indonesia
}

Corresponding author: fajrinsatriagepare@gmail.com

\section{ABSTRACT}

Insurance for the workers means a guarantee of safety for their works on the workplaces. It is necessarily crucial as workers need such a policy that can protect them from the loss. Indonesian government declare a policy that enact the act about National Social Security System (SJSN). The companies are the subject of this regulation, despite the fact at the initial implementation of this law enforcement brought to the pros and cons. Hence, the regulation also regulates for those who betray the policy will have to pay some certain amount of fine which in turn can harden them. The companies on the other side have a choice either to register or not their workers to SJSN as they still consider the premium they have to pay. This study aims to analyze the payoffs for both government and companies to be better off from the law enforcement. Game theory perspective is applied for the methodology of the study, particularly Subgame Perfection Nash Equilibrium (SPNE) and Bayesian Nash Equilibrium (BNE). The results present that in condition of an effective law enforcement at $\mathrm{p}$, the firms will be beneficial from the SJSN policy by registering their workers and pay the premium, because if they do not pay the premium, they have to pay additional amount of fine. On the other hand, if the policy is not effective with l-p, the firms will have an advantage by not registering their employees to the SJSN as the law enforcement is not effective. Also, the government does not necessarily conduct an investigation as the cost is higher than the return that they will get.

Keywords:

Game theory, Law enforcement, BPJS, SJSN, SPNE, BNE 


\section{INTRODUCTION}

The Government of the Republic of Indonesia has enacted Law No 40 the year 2004 about National Social Security System (SJSN). The purpose of SJSN is that workers and their family is protected from accidents, sickness, or death (Gultom, 2016). The principle of the SJSN is mandatory for all working age workers to be registered with SJSN. The first stage of the implementation SJSN is to cover all the formal sector workers and continue to the next stage which is for the informal sector workers (fisherman, farmers, and entrepreneurship). To achieve the goals, the Government set up a separated business entity named BPJS Ketenagakerjaan, which is the only administering body of social security for employees in Indonesia (BPJS Ketenagakerjaan, 2019).

In 1992, the Government enacted Law No 3. of 1992 on Workers Social Security. Through Government Regulation No.36 of 1995, The Government established PT Jamsostek as the Social Security Administering Body for Employment. Furthermore, in 2011, the Government enacted Law No.24 of 2011 on Social Security Agency (BPJS). As stipulated by the Law, on January 1, 2014, PT Jamsostek changed into the public legal entity and transformed into BPJS Ketenagakerjaan and fully operating on July 1, 2015. BPJS Ketenagakerjaan was appointed by the Government to manage workers social security programs, which include Work Accident Benefit (JKK), Provident Fund Benefit (JHT), Pension Benefit, and Death Benefit according to the Law on Social Security System (SJSN).

The people of Indonesia social welfare are provided by this scheme of policy from the social security program. The program expectedly aims to make citizens satisfied for their fundamental needs as the protection of their future loss (Arianto, 2017). Indonesian government as caretaker ensuring the program running as planned regulates this sort of program. In conformity with Amendment of the 1945 Constitution, the central Government is obligated to provide social and economic protection to the people of Indonesia. As part of the constitutional mandate implementation, the Government of Indonesia shall develop social insurance program based on funded social security. The program in the form of social security, in which is funded by the participants. The social security program is implemented with the establishment of PT Jamsostek which later on been renamed with BPJS Ketenagakerjaan.

According to the legislation, Firms are obligated to register all their workers to the SJSN. The worker pays a premium based on the percentage of their earnings to the firms, and then the firms transfer the money to BPJS Ketenagakerjaan. One of the method that BPJS Ketenagakerjaan uses to assure that the Firms obey the law is by doing routine or on the spot investigation. The investigation is subject to the entire firm that has licensed and permitted to do their business from the government. If caught not register or not paying the premium, Firms can be fined a large sum of money.

In general, business activities of BPJS Ketenagakerjaan consist of:

a. Receiving participant registration and membership data management

b. Receiving membership contributions and payments of benefit by the provi- 
sion of social security programs

c. Managing Social Security Funds

d. Managing and distributing participant's welfare facilities.

BPJS Ketenagakerjaan goals are to increase active membership from 16.8 million workers in 2014 to 45.6 million workers in 2018, as well as to improve law enforcement function on the rate of membership to improve participants' compliance to $80 \%$ in 2018 .

The business process of the BPJS Ketenagakerjaan are shown on figure 1.

According to Government Regulation No 44,45 and 60 of 2015, BPJS Ketenagakerjaan have the authority to investigate, imprison and place fined on firms that are not fully registered its workers or not paying the premium. Also in Government Regulation, No 86 of 2013 about Imposing Administrative Sanctions to Employee, Workers, and Recipients of Social Security.

The definition of registered workers is for every individual that has been working in Indonesia at least six months; Firms are obligated to register all of its workers according to the social insurance scheme that he/she registered. BPJS Ketenagakerjaan has specialized recruit employee that will carry the duty of investigation. BPJS Ketenagakerjaan has co-operated with the local district attorney to collect the unpaid premium, fined or other legal matters.

\section{METHODOLOGY}

This project aims to analyze the effectiveness of the law enforcement especially investigation that is done by BPJS Ketenagakerjaan by implementing the perspective of game theory as well as comparing to the real-life result.

The first step to solve the game is to form some basic assumptions of the game, which are as follows.

a. The Companies are a foreign company that employs local workers and foreign workers. We assume that the company have bad intention of not joining and paying the fee for workers insurance under BPJS Ketenagakerjaan.

b. The Companies are located in Capital

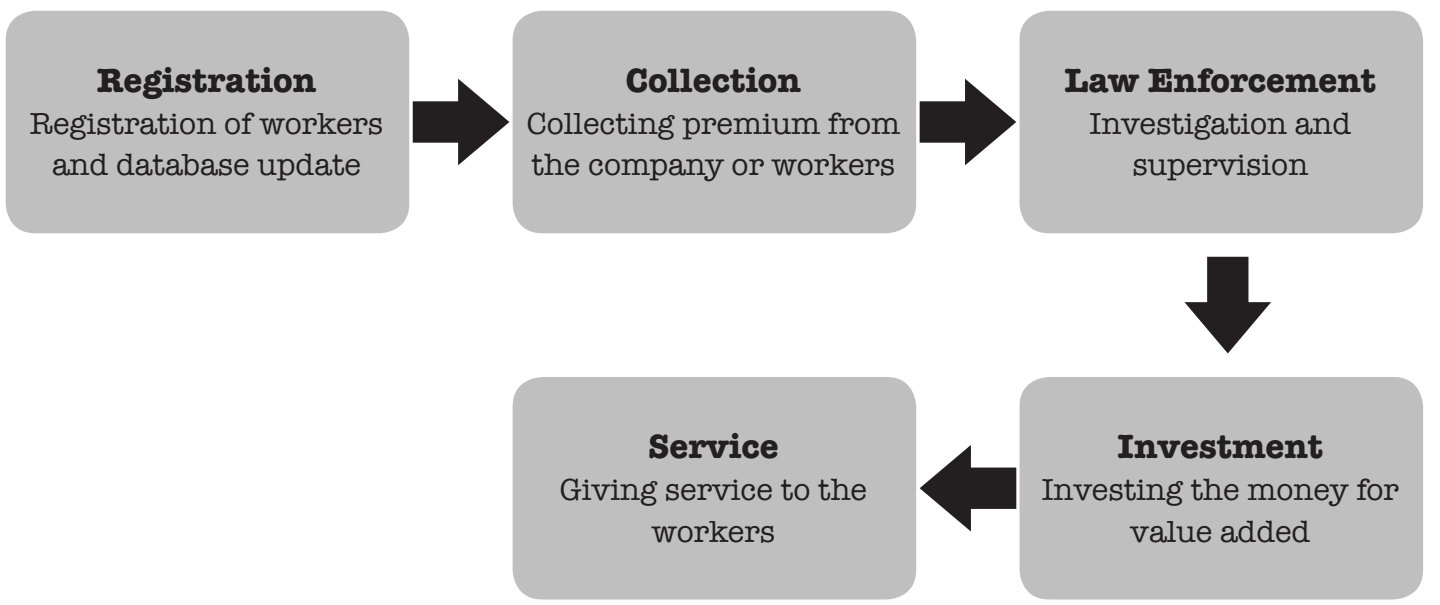

Figure 1. Process of BPJS Ketenagakerjaan Business 
City of Indonesia (Jakarta), so the minimum wage for a worker to calculate the payoff is applied. The minimum wage for a worker in Jakarta for the year 2017 is Rp3,355,750.00 per months.

c. The companies have to pay a sum of money to the BPJS Ketenagakerjaan for every worker that is registered to the insurance scheme

d. The government is doing a routine inspection or supervision for all the companies in Jakarta, seeing whether they comply or not with the law. It means the companies registering do not pay the entire premium that should be collected from the workers to BPJS Ketenagakerjaan, or they do not register their workers to BPJS Ketenagakerjaan, which means they must pay the penalty.

e. The cost of doing supervision (equated as $\mathrm{C}$ ), where:

1. $\mathrm{C}_{1}$ is the cost of inspection/supervision if the companies register but do not pay the premium.

2. $\mathrm{C}_{2}$ is the cost of inspection/supervision if the companies do not register and consequently not paying the premium.

3. $\mathrm{C}_{3}$ is the cost of inspection/supervision, if the companies are not registered by law (do not have a license), meaning BPJS Ketenagakerjaan does not have the company data. Hence, they do not pay the premium.

Therefore, the cost are $\mathrm{C}_{1}<\mathrm{C}_{2}<\mathrm{C}_{3}$.

\section{f. Players}

This game has two players, which are:

1. Player 1 is the Firms that employ the workers. They act on behalf of the workers.

2. Player 2 is the Government and is represented by BPJS Ketenaga- kerjaan as the national institution for managing worker insurance.

g. Payoffs

1. The Game start with nature move where the Firms do not know the effectiveness of law enforcement BPJS Ketenagakerjaan. It is believed that the investigation done by the government is effective with the probability of $p$ and not effective with the probability of $1-p$, where $0 \leq p \leq 1$.

2. Firms as player 1 have the first move and choose whether to register or not register their workers, with the probability of $p$ of $1 / 2$ that the law enforcement is effective.

Assume that Firms decide to obey the regulation and register their workers, thus will have to pay the premium to the Government (BPJS Ketenagakerjaan) nominated with $Y$. The calculation for finding the payoff is:

$Y=(\%$ insurance $) x$ (minimum wage per worker per month) $x$ (number of workers)

Then, the Firms payoff will be $-Y$, and the Government receives the premium as the payoff of $Y$. If the Firms decides not to pay the premium to the Government, then the Government as player two can launch an investigation to the Firms, and if effective, the Firms will have to pay the premium plus penalty fined for breaking the regulation. The amount of fine or penalty according to regulation is Rpl.000.000.000,00 or simply nominated by $1 \mathrm{~B}$. The Government receives the premium and the fine, but also costs for the investigation of $\mathrm{C}_{1}$. 
Firms payoff $=-Y+(-1 B)$

Government payoff $=(Y+1 B)-C_{1}(3)$

If the Government does not investigate, then the Firms can keep the money from premium as the payoff, and the Government earns nothing.

3. If the Firms decide not register, then the Government can investigate the Firms. Due to lack of human resources, BPJS Ketenagakerjaan cannot investigate all the Firms indicated not registering and not paying the premium. The cost of the audit will be $\mathrm{C}_{2}$, which is more costly than $C_{1}$ because BPJS Ketenagakerjaan has to put more resources to located and investigate the Firms.

Firms payoff $=-Y+(-1 B)$

Government payoff $=$

$(Y+1 B)-C_{2}$

4. If the Law enforcement is not effective with the probability of 1 $\mathrm{p}$, the Government cannot collect the fined due to lack of evidence. If the Government does not have enough information to distinguish the Firms, then Government can only collect the premium with the cost of investigation, which is larger than the previous investigation, due to more resources needed.

Firms payoff $=-Y$

Government payoff $=Y-C_{3}$

5. The Government is still mandatory to perform an investigation to Firms, Due to the nature of the ineffective investigation, the Firms that are not registered can keep the premium ( $\mathrm{Y}$ ) and the Government have to put additional cost to investigate $\left(-\mathrm{C}_{3}\right)$.

6. Solving the Game

- Subgame Perfection Nash Equlibrium (SPNE) Reinhard Selten (1965) introduced the solution concept of subgame perfect Nash equilibrium (SPNE) for games with imperfect information. Yildiz (2012) defined a subgame as an embedded smaller extensive-form game to larger game. If the equilibrium of the subgame in backward induction is recomputed via backward induction, subgame perfection generalizes it to general dynamic games, in which a Nash equilibrium is defined as subgame perfect if an only if it is a Nash equilibrium in every subgame of the game.

Watson (2013) examined that to play the game; it is started from the end of the game just like in backward induction. As the game is in imperfect information, the only way to identify its $\mathrm{NE}$ is to reduce it to its normal form. The order of payoffs need to take more consideration as they are presented for the entire game, for example $\mathrm{Pl}$ first and then P2. After forming all imperfect information into their respective normal form and find each best response, the next move is to construct as the whole game through analyzing the normal form of the 
game. Theoretically, every finite extensive form game with perfect recall possesses a subgame perfect NE.

- Bayesian Nash Equilibrium (BNE)

To allow some uncertainty to be introduced in a game, a non-strategic player called Nature is applied (Watson, 2013). Nature attributes sorts of players, or identifies the realization of random events. Therefore, the game can be moved firstly with Nature's move, in which $\mathrm{p}$ represents the probability of occurred event while 1 - p means the event does not occur.

The first step to apply the game with $\mathrm{BNE}$ is by making the strategy space for both players. From the strategy spaces, we then can find the BNE by transforming the game tree into the normal forms; hence, we can compute each payoffs by involving nature's move.

By combining both payoffs matrices, Bayesian normal form of the game the can be presented, including the uncertainty involved by the players. The value of probability of $\mathrm{p}$ is the assumed to allow calculating the real payoffs from the game. It is finally the identification of $\mathrm{BNE}$ in pure strategies is obtained.

\section{RFSULTS AND DISCUSSION}

The assumptions to play the game can be turned into its extensive form that also

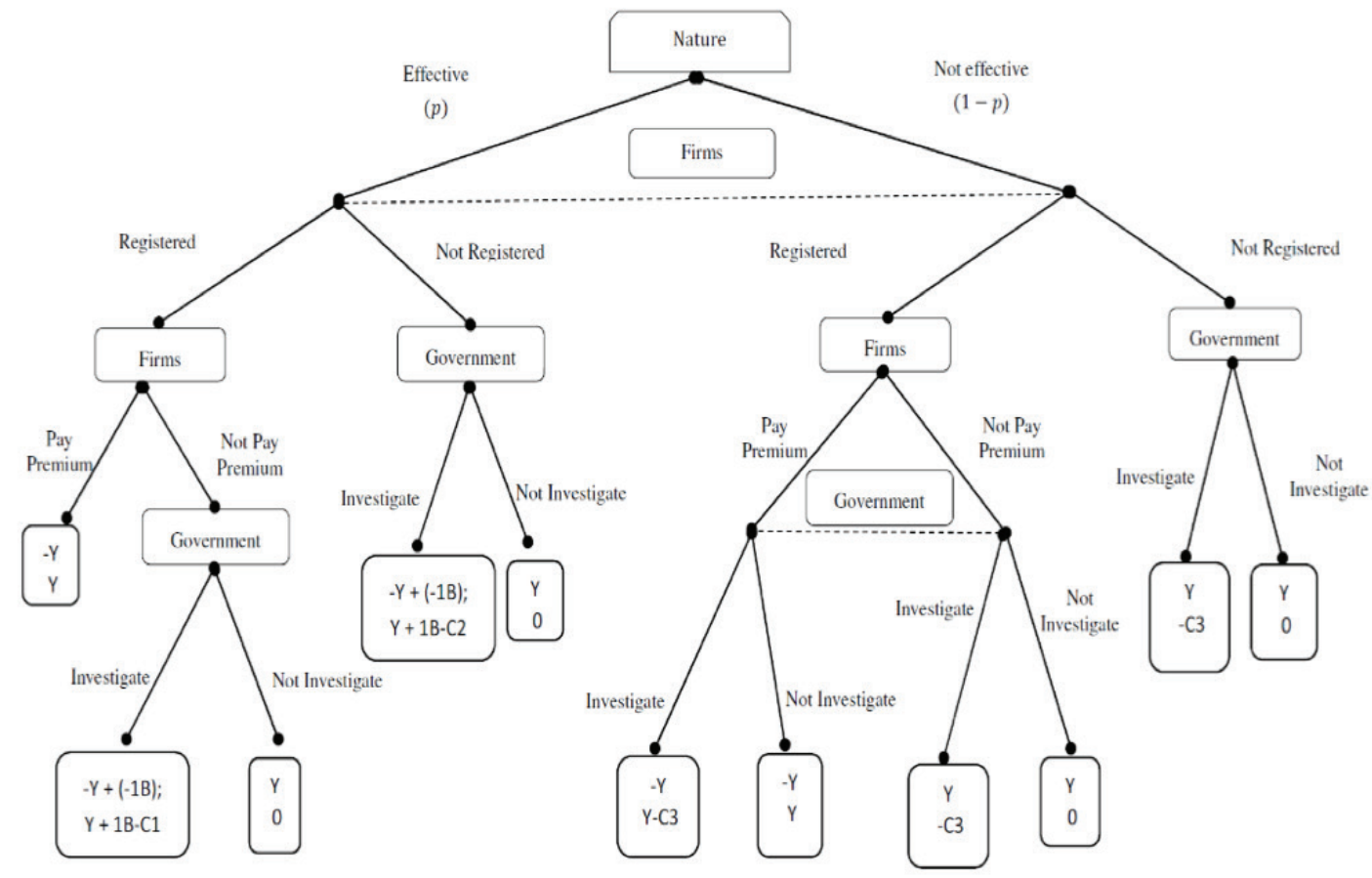

Figure 2. Extensive form of BPJS Ketenagakerjaan 
captures the nature's move as ..

Where:

- $\mathrm{Y}=$ Premium paid to the Government.

- $\quad \mathrm{IB}=$ One billion rupiah (the amount of fine for the Firms not paying premium).

- $\mathrm{C}=$ cost for doing investigation $\left(\mathrm{C}_{1}<\right.$ $\mathrm{C}_{2}<\mathrm{C}_{3}$ ).

- $\quad$ Player $1=$ the Firms

- $\quad$ Player 2 = the Government

To solve the game, the application of backward induction for the perfect subgame, SPNE for imperfect subgame and Bayesian Nash Equilibrium (BNE) are applied.

\section{Backward Induction (BI)}

- Solve for the first subgame when nature is effective and the Firms register to the policy. Here the Government as player 2 takes the first turn for BI.

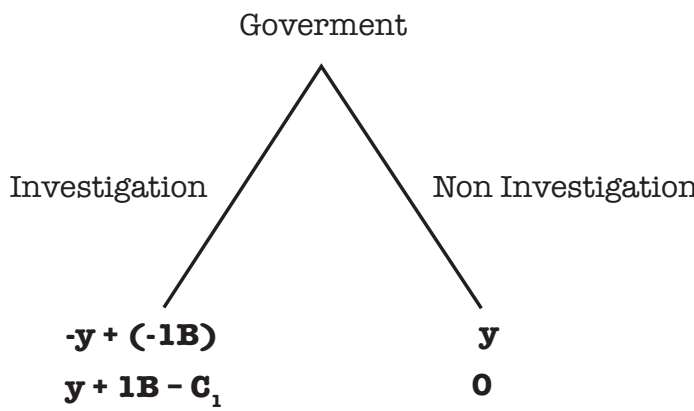

Government will choose to do investigation as its best response for higher payoffs, where government will accept some premium plus 1 billion rupiah fine deducted by cost grade 1, otherwise nothing. Hence, backward induction Nash equilibrium (BINE) for government is to do investigation, or can be mathematically simplified as:

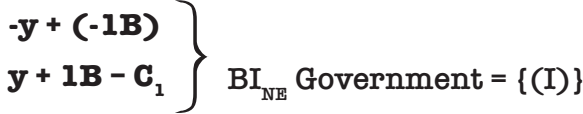

- Solve for the second subgame for the Firms after knowing the government will be better off if investigation applied in effective nature's move.

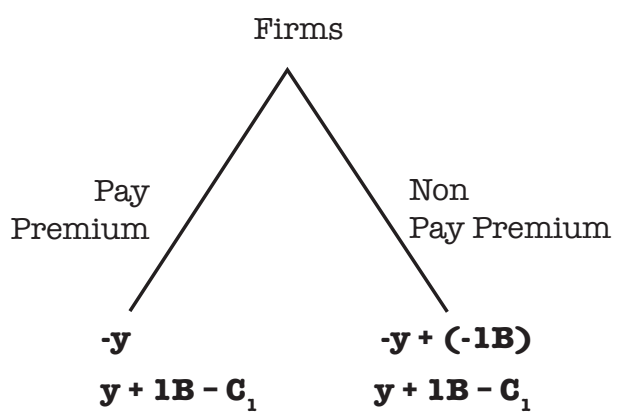

- Firms will prefer to pay the premium to the Government (-y), instead of by not obeying the policy they will be fined by another one billion rupiah. Thus, the BINE for the Firms is to pay premium, or:

$$
\left.\begin{array}{l}
-\mathbf{y} \\
\mathbf{y}
\end{array}\right\} \mathrm{BI}_{\mathrm{NE}} \text { Firms }=\{(\mathrm{P})\}
$$

\section{Subgame Perfection}

When nature is not effective, the subgame is imperfect information. The condition is that the Firms obey the regulation but the Government has imperfection information regarding the Firms pay or not for the premium. Therefore, to find its Nash equilibrium $(\mathrm{NE})$, the subgame perfection needs to transform into normal form.

Transform to normal form: 


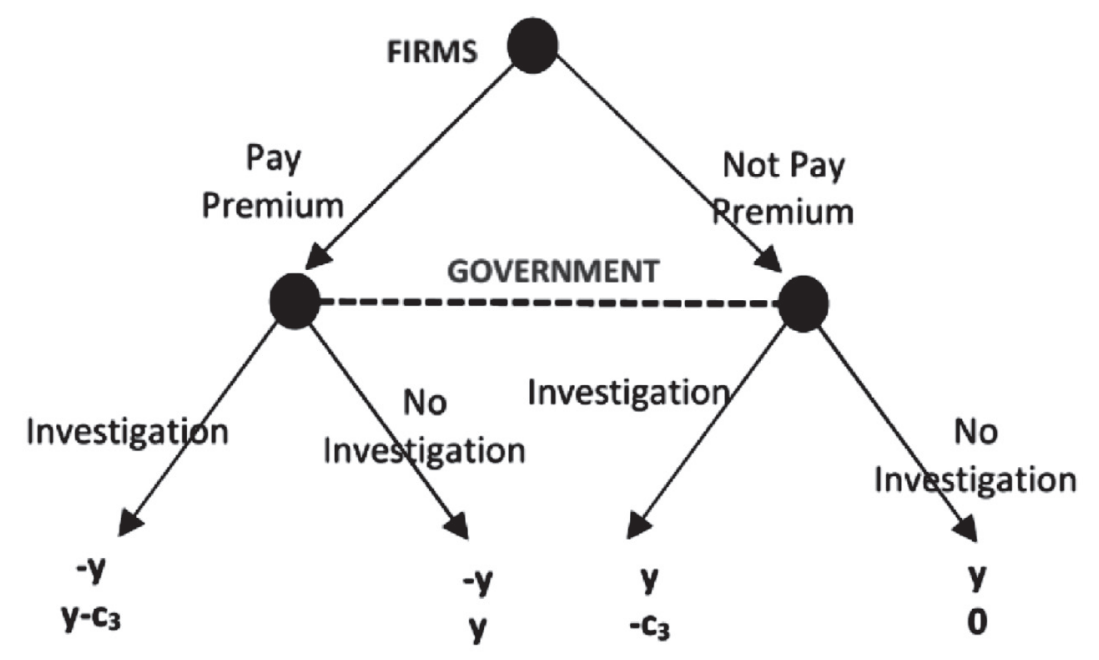

$\mathrm{S}_{1}=\{$ Pay, Not Pay $\}$

$\mathrm{S}_{2}=\{$ Investigation, No Investigation $\}$

see Figure 3.

Table 1. Normal Form of Subgame Perfection in Non-Effective Nature

\begin{tabular}{|c|c|c|c|}
\hline & \multicolumn{2}{|c|}{ Government } \\
\hline & & Investigation & $\begin{array}{c}\text { No } \\
\text { Investigation }\end{array}$ \\
\hline द्वे & Pay & $-\mathrm{y} ; \mathrm{y}-\mathrm{C}_{3}$ & $-\mathrm{y} ; \mathrm{y}$ \\
\hline 望 & Not Pay & $\mathrm{y} ;-\mathrm{C}_{3}$ & $\underline{\mathrm{y}} ; \underline{\mathrm{O}}$ \\
\hline
\end{tabular}

The Nash equilibrium is that Firms choose not to pay premium and Government prefer not to run the investigation.

$\mathrm{NE}=\{$ not pay', no investigation' $\}$

$$
\mathrm{NE}=\left\{\mathrm{NP}^{\prime}, \mathrm{NI}^{\prime}\right\}
$$

From the three subgames solved by backward induction and subgame perfection, then it allows us to find its Subgame Perfection Nash Equilibrium (SPNE), which is:

SPNE: \{(pay, investigation), (not pay', no investigation')\}; or

SPNE: $\left\{(P, I),\left(N^{\prime}, N^{\prime}\right)\right\}$

Therefore, the game can be reduced into,

3. Bayesian Nash Equilibrium (BNE)

From the reduced game tree, we then can set the strategy space for both players to solve BNE, which are as follows.

$\mathrm{S}_{1}=\{$ register, not register $\}$; or

$\mathrm{S}_{1}=\{\mathrm{R}, \mathrm{NR}\}$

$\mathrm{S}_{2}=\{$ (investigation, investigation'), (investigation, no investigation'), (no investigation, investigation'), (no investigation, no investigation')\}; or $\mathrm{S}_{2}=\{$ I I', I NI', NI I', NI NI' $\}$

From the strategy space $S_{1}$ and $S_{2}$, it then can be made the matrices of payoffs, which are as shown in Table 2 and Table 3.

Matrices from table 2 and 3 are then combined for identifying the Bayesian Nash Equilibrium (BNE), as presented on table 4 .

Table 4 makes it clear that the BNEs are the Firms will register for the Government's investigation in both effective and non-effective nature; the Firms will register while the Govern- 


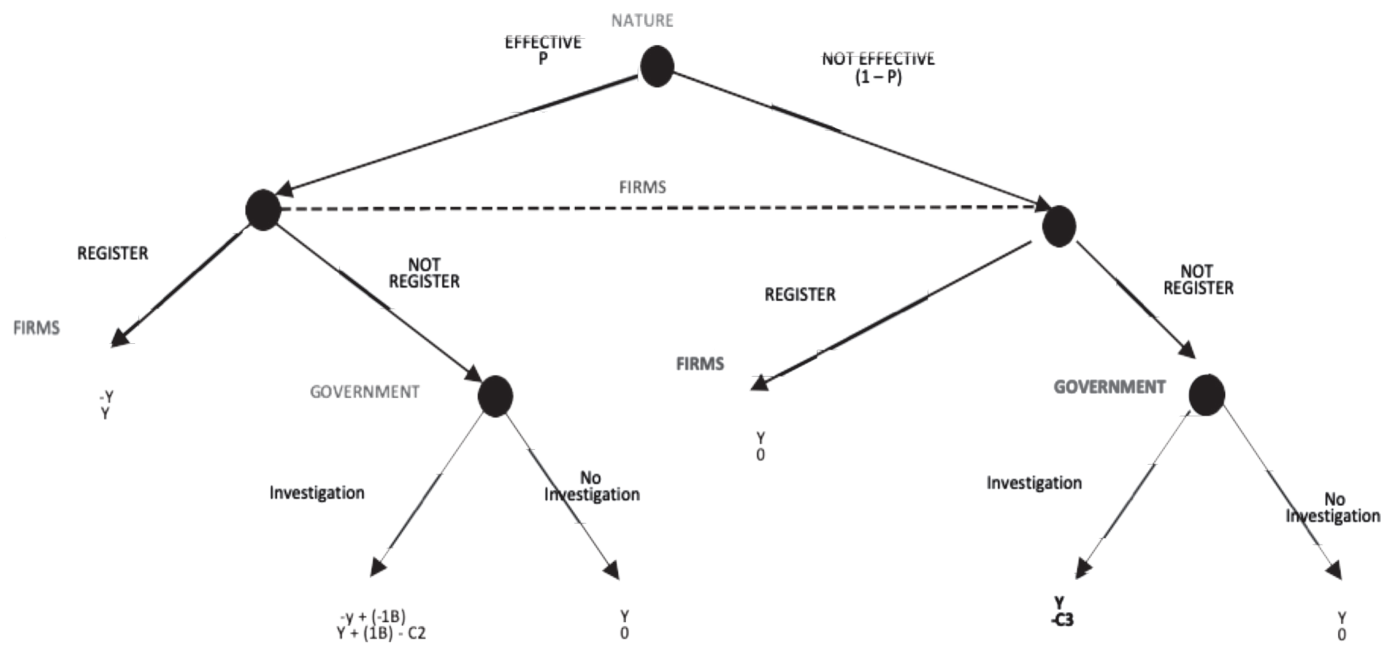

Figure 3. Reduced Game after Finding its SPNE

a $\mathrm{n} \mathrm{d}$ will

ment will do investigation if effective,

Table 2. Player 1's Payoffse

\begin{tabular}{|c|c|c|c|c|c|}
\hline \multirow{2}{*}{\multicolumn{2}{|c|}{$\begin{array}{l}\text { Payoff for } \\
\text { player } 1\end{array}$}} & \multicolumn{4}{|c|}{ GOVERNMENT } \\
\hline & & I I' & I NI' & NI I' & NI NI' \\
\hline \multirow{5}{*}{ FIRMS } & $\mathrm{R}$ & $-Y(p)+Y(1-p)$ & $\begin{array}{l}-Y(p)+ \\
Y(1-p)\end{array}$ & $\begin{array}{l}-Y(p)+Y(1- \\
p)\end{array}$ & $\begin{array}{l}-Y(p)+Y(1- \\
p)\end{array}$ \\
\hline & $\mathrm{NR}$ & $\begin{array}{l}(-Y-1 B)(p)+ \\
Y(1-p)\end{array}$ & $\begin{array}{l}(-Y-1 B)(p)+ \\
Y(1-p)\end{array}$ & $\begin{array}{l}Y(p)^{+} \\
Y(1-p)\end{array}$ & $Y(p)+Y(1-p)$ \\
\hline & \multicolumn{5}{|c|}{$=$} \\
\hline & $\mathrm{R}$ & $\mathrm{Y}-2 \mathrm{pY}$ & $\mathrm{Y}-2 \mathrm{pY}$ & $\mathrm{Y}-2 \mathrm{pY}$ & $\mathrm{Y}-2 \mathrm{pY}$ \\
\hline & $\mathrm{NR}$ & $Y-2 p Y-1 B p$ & $Y-2 p Y-1 B p$ & $\mathrm{Y}$ & $\mathrm{Y}$ \\
\hline
\end{tabular}

Table 3. Player 2's Payoffse

\begin{tabular}{|c|c|c|c|c|c|}
\hline \multirow{2}{*}{\multicolumn{2}{|c|}{$\begin{array}{l}\text { Payoff for player } \\
2\end{array}$}} & \multicolumn{4}{|c|}{ GOVERNMENT } \\
\hline & & I I' & I NI' & NI I' & NI NI' \\
\hline \multirow{5}{*}{ FIRMS } & $\mathrm{R}$ & $Y(p)+O(1-p)$ & $Y(p)+O(1-p)$ & $Y(p)+O(1-p)$ & $Y(p)+O(1-p)$ \\
\hline & NR & $\begin{array}{l}\left(Y+1 B-C_{2}\right)(p)+\left(-C_{3}\right) \\
(1-p)\end{array}$ & $\begin{array}{l}\left(Y+1 B-C_{2}\right) \\
(p)+O(1-p)\end{array}$ & $\begin{array}{l}O(p)+\left(-C_{3}\right) \\
(1-p)\end{array}$ & $O(p)+O(1-p)$ \\
\hline & \multicolumn{5}{|c|}{$=$} \\
\hline & $\mathrm{R}$ & Yp & Yp & Yp & Yp \\
\hline & NR & $\mathrm{Yp}+1 \mathrm{Bp}-\mathrm{C}_{2} \mathrm{p}-\mathrm{C}_{3}+\mathrm{C}_{3} \mathrm{p}$ & $\mathrm{Yp}+1 \mathrm{Bp}-\mathrm{C}_{2} \mathrm{p}$ & $-\mathrm{C}_{3}+\mathrm{C}_{3} \mathrm{p}$ & 0 \\
\hline
\end{tabular}

Table 4. Payoffs Matrices for Both Players

\begin{tabular}{|c|c|c|c|c|c|}
\hline \multirow{2}{*}{\multicolumn{2}{|c|}{$\begin{array}{l}\text { Payoffs for } \\
\text { Both Players }\end{array}$}} & \multicolumn{4}{|c|}{ GOVERNMENT } \\
\hline & & $\mathrm{II}^{\prime}$ & I NI' & NI I' & NI NI' \\
\hline \multirow[b]{2}{*}{ FIRMS } & $\mathrm{R}$ & Y-2pY; Yp & Y-2pY; Yp & Y-2pY; Yp & Y-2pY; Yp \\
\hline & $\mathrm{NR}$ & $\begin{array}{l}Y-2 p Y-1 B p \\
Y p+1 B p-C_{2} p-C_{3}+C_{3} p\end{array}$ & $\begin{array}{l}Y-2 p Y-1 B p ; Y p+1 B p- \\
\mathrm{C}_{\curvearrowright} p\end{array}$ & $\mathrm{Y} ;-\mathrm{C}_{3}+\mathrm{C}_{3} \mathrm{p}$ & $\mathrm{Y} ; \mathrm{O}$ \\
\hline
\end{tabular}


no action if not effective. It can be simplified as follows:

BNE: $\left\{\left(\mathrm{R}, \mathrm{I} \mathrm{I}^{\prime}\right),\left(\mathrm{R}, \mathrm{I} \mathrm{NI}^{\prime}\right)\right\}$

Therefore, the overall Nash equilibrium, combining SPNE and BNE, is as follow:

$\mathrm{NE}:$ \{(pay, investigation), (not pay', no investigation'), (register; investigation, investigation'), (register; investigation, not investigation'), with any $0<\mathrm{p}<1$ \}, or

$\mathrm{NE}:\left\{(\mathrm{P}, \mathrm{I}),\left(\mathrm{NP}, \mathrm{NI}^{\prime}\right),\left(\mathrm{R}, \mathrm{I} \mathrm{I}^{\prime}\right),(\mathrm{R}, \mathrm{I}\right.$ NI'), with any $\mathrm{O}<\mathrm{p}<1\}$

\section{CONTCLUSION}

The Nash equilibriums show that with the law enforcement effective at (p), the Firms will better off to register and pay the premium; else, if the Firms does register but does not pay the premium, the Firms will loss more due the effective of the law enforcement by the government. If the law enforcement is not effective at $(1-p)$, the Firms will better off by not registering their employees. Since the law enforcement is not effective, the government will not bother to do the investigation because the cost of the investigation is higher than the return for the government. For the summary, the effectiveness of the law enforcement determines whether the Firms will register or not register their workers. The Firms would have the optimum payoffs if the Firms join BPJS Ketenagakerjaan, but with the support of effective investigation by the Government.

\section{RFFERFNCFS}

BPJS Ketenagakerjaan Annual Report, 2016.

Watson, Joel. 2013. Strategy: an Introduction to Game Theory, third edition. W.W Norton \&e Company: New York.

Gultom, Ratih Yasnuarni. 2016. Pengaruh Perkembangan Makro Ekonomi Indonesia terhadapa Pertumbuhan Kepesertaan BPJS Ketenagakerjaan. Jurnal Institut BPJS Ketenagakerjaan, Vol 1.

Arianto, Bimo. 201\%. Menakar Keberhasilan Penyelenggaraan Jaminan Sosial. Jurnal Institut BPJS Ketenagakerjaan, Vol. 2.

Muhamet Yildiz. Spring 2005. 14.147 Topics in Game Theory. Massachusetts Institute of Technology: MIT OpenCourseWare, https://ocw.mit.edu. 